\title{
PROTECTIVE EFFECT OF NIGELLA SATIVA OIL ON TESTICULAR MORPHO-PHYSYLOGICAL CHANGES INDUCED BY CHRONIC ALCOHOLISM IN ALBINO RATS
}

\author{
Nadia M. EI - Rouby and Romysa A. EI - Sherbeny* \\ Histology Department, Faculty of Medicine, Cairo University \\ and Physiology Department, Faculty of Medicine, Tanta University*
}

\section{INTRODUCTION}

Alcoholism is an illness caused by consumption of alcohol beverages at a level that interferes with physical or mental health, and social, family, or occupational responsibility. People with alcohol dependence have to increase markedly amounts of alcohol to achieve intoxication or the desired effect (Thomas, 2003).

Alcoholism affects 15 to 20 million Americans and affects three to four times as many family members, coworkers, and friends. It is involved in half of all fatal automobile accidents and is responsible for more than 100,000 deaths annually. representing about $5 \%$ of all deaths in the United States. Fetal alcohol syndrome is the third leading cause of birth defects with accompanying mental retardation (Michigan society for medical research, 2003).

Acute and chronic alcoholism carry the potential to damage many organs of the body, including the heart, brain, liver, kidney, digestive system and reproductive system (erectile dysfunction and cessation of menstruation). When alcohol was given. its level in the body increased and produced the intoxication effects. The undesirable toxic effects include damage of Leydig cells and spermatogenic lineage cells (Michigan society for medical research, 2003).

Zinc is essential for normal growth and reproduction and it has a beneficial effect on the process of tissue repair and wound healing (King, 1990). Zinc is a constituent of antioxidant, superoxide dismutase. It is also needed for proper maintenance of vitamin $E$ level in the blood and aids in the absorption of vitamin A (Bert and Falchuk, 1993). It exerts a protective effect and possibly preventing cellular damage caused by oxidative stress (Marchesini et al., 1996). 
Zinc metalloenzymes include 200 related enzymes for which zinc is needed. that participate in the metabolism of lipids, carbohydrates. synthesis of protein and nucleic acids. Zinc has a metabolic role under various physiological and pathological conditions (Vallee, 1998). Both zinc and copper are cofactors in metalloenzymzs $\mathrm{Cu}^{+2}, \mathrm{Zn}^{+2}$, superoxide dismutase, and $\mathrm{Zn}^{+2}$ competes $\mathrm{Cu}^{+2}$ for the binding sites (Sharonova et al., 2000).

Copper is highly toxic in excess, and results in cellular damage. Reduction of ceruloplasmin oxidase activity results in free radical release and this may cnhance oxidative damage of cells (Eagon et al., 1999).

Selenium is an important component of the antioxidant enzyme glutathione peroxidase (Anumann et al., 1997) Glutathione peroxidase stimulation of catalytic cycle, in synergism with vitamin $\mathrm{E}$. it also enhances the immune system in clderly (Clarrk et al,, 1998).

Black seed (Nigella sativa), a member of the Runuculaceae family, is one of the native plants that are widely distributed in Egypt. Nigella sativa and its constituents have been widely used in folk medicine and experimental animal studies (Hassan. and EI Dakhakhny, 1992). In Arabian folk medicine. it is used for treatment and prevention of many discases like bronchial asthma, diabetes, theumatism and hypertension. Also, Nigella sativa was used to elevate the immunity of the individual (E1 Kadi et al., 1987). Nigella sativa seeds and its constituents have anti oxidant action (capable of scavenging oxygen derived free radicals), anti tumor activity, digestive stimulant, and an immune modulating effect. Also, it has been reported that Nigella sativa has a cyto-protective effect on tissues exposed to cytotoxic agents (EI - Kadi et al., 1987; Hassan. and El Dakhakhny, 1992).

The present work was done to investigate the morphophysiological changes of albino rat testicles exposed to experimental chronic alcohol intake for 30 days and also, to detect if oral administration of Nigella sativa oil has any role in prevention of these effects, if any.

\section{MATERIAL AND METHODS}

The present study was carried out on 40 adu! male albino rats weighing 250 $300 \mathrm{gm}$. The animals had free access of water and wandard diet of milk and bread. The rats were divided into four equal groups.

- Group 1 : Is the control group. 
- Group 2 : Received oral Nigella sativa oil obtained from (PharcoPharmaceutical- Alexandria - Egypt), daily in a dose of $0.88 \mathrm{gm} / \mathrm{kg}$. B.W. (El-Dakhakhny et al., 2000) for 30 days.

- Group 3 : Animals were given oral $40 \%$ efhanol (ethyl alcohol) daily in a dose of $3 \mathrm{ml} / \mathrm{kg}$. B.W. (Gamal, 2001).

- Group 4 : Animals were given oral $40 \%$ cthanol in a dose of $3 \mathrm{ml} / \mathrm{kg}$. B.W. daily for 30 days and at the same time rats were administered Nigella sativa oil orally in a dose of $0.88 \mathrm{gm} / \mathrm{kg}$. B.W. daily.

After 30 days all rats were weighed before decapitation. After decapitation, blood samples were taken and centrifuged to separate serum. Serum is used to estimate Testosterone according to (Stlay et al., 1996). Leutinizing hormone (LH) and Follicular stimulating hormone (FSH) according to (Kullin and Santier, 1996). For determination of trace elements $\left(\mathrm{Zn}^{+2}, \mathrm{Cu}^{+2}, \mathrm{Se}^{+2}\right)$, microanalysis of energy dispersive X-ray florescence technique (EDXF), and Neutron activation analysis technique (NAAT) were used (EI Nimer et al., 1996; EI Nimer et al., 1996).

The testicles werc dissected, weighed, immediately fixed in Bouin's solution, and then prepared for histological examination.

\section{RESULTS}

The results of the present work showed that :

\section{General Examination :}

Rats of group (1), and (2) showed insignificant increase in body weight, normal amount of food consumption and no deaths during the period of the experiment. Animals of group (3) showed increased mortality rate (20\%). marked reduction in food intake and significant loss of body weight ( $\mathrm{p}$ value $<0.05$ ) as compared to other groups $(1,2)$. The animals of group $(4)$ showed less mortality ratc $(10 \%)$ and insignificant reduction of body weight (Table : 1) (Fig. 1). There was slight increase in the percentage of testicular weight in relation to body weight in rats of group (3). The percentage of testicular weight in relation to the body weight (after 30 days) of the control group was $2.1 \%$, whilc in alcohol treated group was $2.7 \%$ and alcohol plus Nigella treated group was $2.1 \%$ (Fig. 2). 


\section{Blood Examination (Hormonal analysis) :}

The present work showed that, chronic oral alcohol administration for 30 days (group 3) resulted in significant decrease in Testosterone, LH and FSH levels compared with the control group (1) and Nigella Sativa oil treated rats (group 2), ( $<<$ 0.05). In group (4), there was insignificant decrease in Testosterone level compared to the control group $(\mathrm{P}>0.05)$ but a significant reduction was observed as regard FSH and LH $(\mathrm{P}<0.05)$. Also, there was a significant reduction of trace elements, $\left(\mathrm{Zn}^{+2}, \mathrm{Cu}^{+2}, \mathrm{Se}^{+2}\right)$, in rats administered alcohol in comparison to control group $(\mathrm{P}<$ 0.05 ), which improved after intake of Nigella sativa with alcohol in comparison to alcohol treated group, $(\mathrm{P}<0.05)$ (Table 2$)$ and (Figs. 3 - 8).

\section{Histological Examination :}

Testicular morphology of rats in group (2), which administered Nigella Sativa oil, resembled that of the control group (group; 1), (Figs. 9 - a \& 9 - b).

Testicular pattern of rats in group (3), which was given alcohol only showed that the capsular blood vessels were dilated and congested (Fig. 10 - a). The seminiferous tubules were widely separated from each other and revealed reduction in the diameter (Fig. 10 - b). There was partial separation of the basement membrane of some seminiferous tubules. Also, there was a significant decrease in the number of sperms, as well as spermatogenic lineage cells. Other tubules were nearly empty from spermatogenic cells. The number of spermatogonia was markedly increased in the highly affected tubules. In some tubules, the spermatogenic cells were arrested at primary sepermatocyte stage, others were arrested at spermatid stage, (Fig. 11 - a). The seminiferous tubules showed thickening of the basement membrane (Fig. 11 b). Vacuoles were secn within the seminiferous tubules (Fig. 12 - a). The interstitial tissue revealed scanty number of Leydig cells, hyalinization, edema, dilated and congested blood vessels (Fig. 12 - b).

Testes of animals in group (4). which was treated with alcohol and Nigella sativa oil at the same time, showed more or less the same testicular morphology as in groups (1 \& 2) as in (Fig. 13). 
Table 1 : Shows the body weight in grams before and after 30 days, of the control group, alcohol treated group, and alcohol plus Nigclla sativa treated group.

\begin{tabular}{|c|c|c|c|}
\hline Item & Mean & SD & T test P value \\
\hline Control Before & 275.8 & 18.6 & $0.14^{*}$ \\
\hline Control After & 287.2 & 16.9 & \\
\hline Alcohol Before & 261.7 & 26.7 & $0.04^{*}$ \\
\hline Alcohol After & 233.3 & 26.8 & \\
\hline $\begin{array}{c}\text { Alcohol + Nigella } \\
\text { Before }\end{array}$ & 256.7 & 39.9 & $0.13^{*}$ \\
\hline $\begin{array}{c}\text { Alcohol + Nigella } \\
\text { After }\end{array}$ & 299.3 & 42.6 & \\
\hline
\end{tabular}

* insignificant p value compared to control.

* Significant value as $(p<0.05)$.

Table 2 : Shows the effect of oral Nigella sativa oil on serum testosterone. LH. $\mathrm{FSH}, \mathrm{Zn}^{+2}, \mathrm{Cu}^{+2}$, and $\mathrm{Sc}^{+2}$ levels in alcohol administrated albino rats.

\begin{tabular}{|c|c|c|c|c|c|c|}
\hline Item & $\begin{array}{c}\text { Testosterone } \\
\text { (ng/ml) } \\
\text { Mean (6) } \\
\mathrm{SE}+/ \cdot \mathrm{T}\end{array}$ & $\begin{array}{c}\text { LH } \\
\text { (m.t.u. } / \mathrm{mi}) \\
\text { Mean }(6) \\
\mathrm{SE}+/-\mathrm{T}\end{array}$ & $\begin{array}{c}\text { FSH } \\
\text { (m.i.u. } / \mathrm{ml}) \\
\text { Mean (6) } \\
\text { SE+/.T }\end{array}$ & $\begin{array}{l}\text { Zinc (11g/ } \\
\text { lo0mi } \\
\text { blowd) } \\
\text { Mean (6) } \\
\text { SE + - T }\end{array}$ & $\begin{array}{c}\text { Copper (ug } \\
\text { / looml } \\
\text { blood) } \\
\text { Mean (6) } \\
\text { SE+/ - T }\end{array}$ & $\begin{array}{c}\text { Selenium } \\
\text { (ug/ 100m) } \\
\text { blood) } \\
\text { Mean (6) } \\
\text { SE+/ - T }\end{array}$ \\
\hline Control & $\begin{array}{l}4.79 \\
0.16\end{array}$ & $\begin{array}{l}3.42 \\
0.1\end{array}$ & $\begin{array}{l}9.68 \\
0.26\end{array}$ & $\begin{array}{l}74.7 \\
0.59\end{array}$ & $\begin{array}{l}39.2 \\
0.47\end{array}$ & $\begin{array}{c}0.35 \\
0.009\end{array}$ \\
\hline Nigella & $\begin{array}{l}4.99 \\
0.15 \\
0.09^{*}\end{array}$ & $\begin{array}{l}3.51 \\
0.04 \\
0.8^{*}\end{array}$ & $\begin{array}{c}10 \\
0.22 \\
0.9^{*}\end{array}$ & $\begin{array}{r}75.8 \\
0.78 \\
0.39 *\end{array}$ & $\begin{array}{l}39.1 \\
0.62 \\
0.12 *\end{array}$ & $\begin{array}{c}0.36 \\
0.008 \\
1^{*}\end{array}$ \\
\hline Alcohol & $\begin{array}{l}4.21 \\
0.13 \\
3.8^{* *}\end{array}$ & $\begin{array}{l}2.95 \\
0.07 \\
4 * *\end{array}$ & $\begin{array}{c}7.51 \\
0.4 \\
4.6 * *\end{array}$ & $\begin{array}{l}26.1 \\
0.39 \\
69^{* *}\end{array}$ & $\begin{array}{c}25.1 \\
0.41 \\
22.5 * *\end{array}$ & $\begin{array}{c}0.15 \\
0.005 \\
20^{4 k}\end{array}$ \\
\hline $\begin{array}{c}\text { Alcohol + } \\
\text { Nigella }\end{array}$ & $\begin{array}{l}4.69 \\
0.06 \\
1.64^{*}\end{array}$ & $\begin{array}{c}3.11 \\
0.05 \\
2.9 * *\end{array}$ & $\begin{array}{c}8.2 \\
0.1 \\
5.4 * *\end{array}$ & $\begin{array}{l}45.8 \\
0.58 \\
35^{* *}\end{array}$ & $\begin{array}{l}36 \\
0.44 \\
4^{* * k}\end{array}$ & $\begin{array}{c}0.24 \\
0.0117 \\
11 * *\end{array}$ \\
\hline
\end{tabular}

$\mathrm{T}^{*}$ : insigniticant $\mathrm{p}$ value compared to control.

$T^{* *}$ : Significant p value compared to control $(p<0.05)$. SE : Standard crror. 


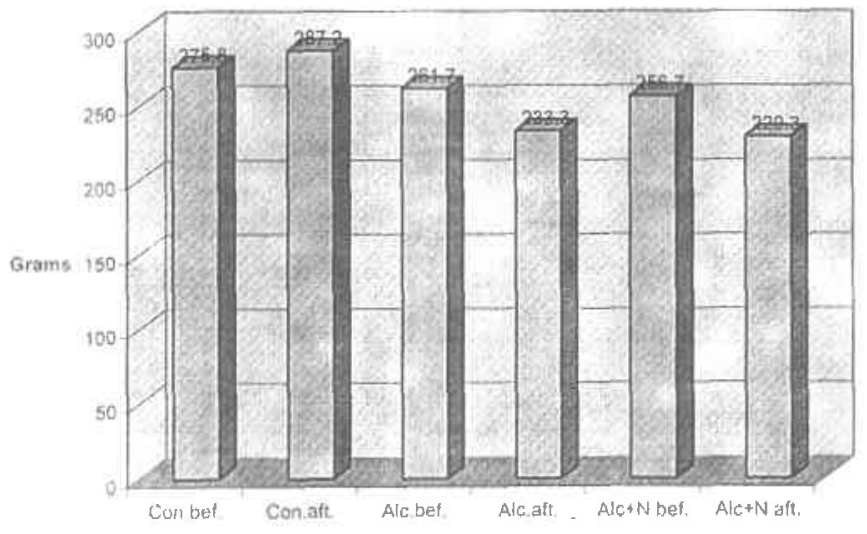

Fig. (1) : Body weight of the different groups before and after the study.

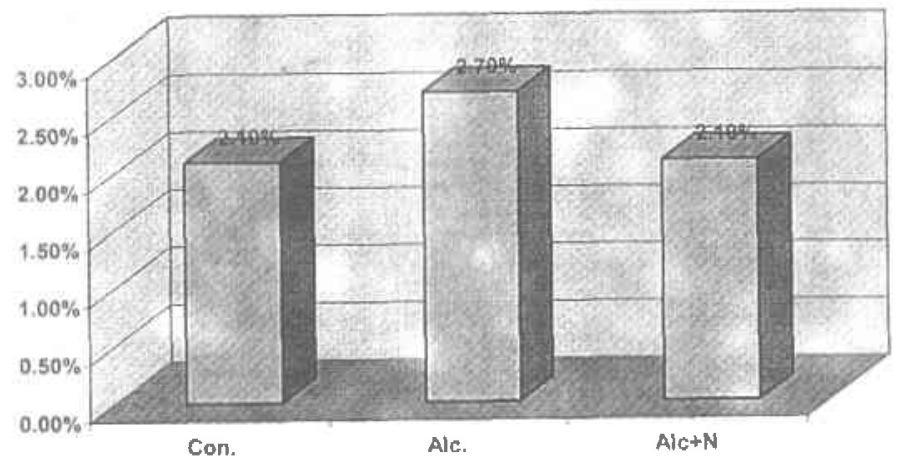

Fig. (2) : Percentage of testicular weight / body weight. 


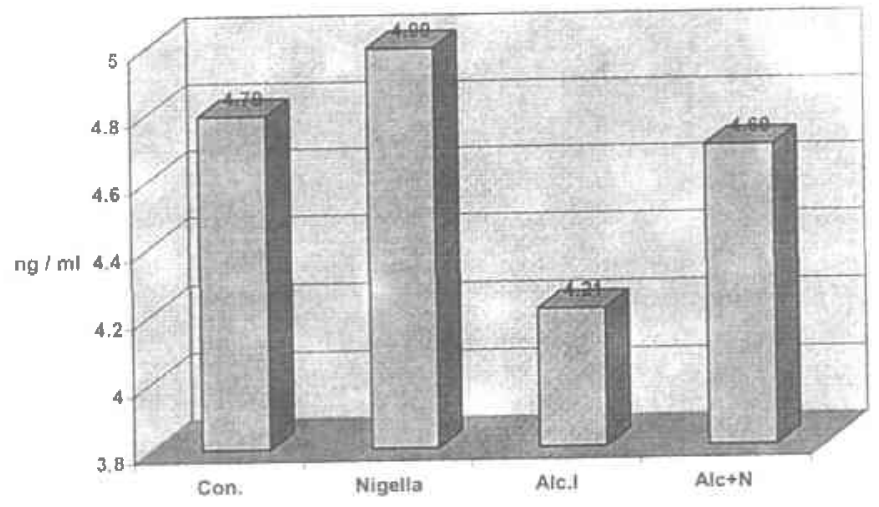

Fig. (3) : Serum testosterone level.

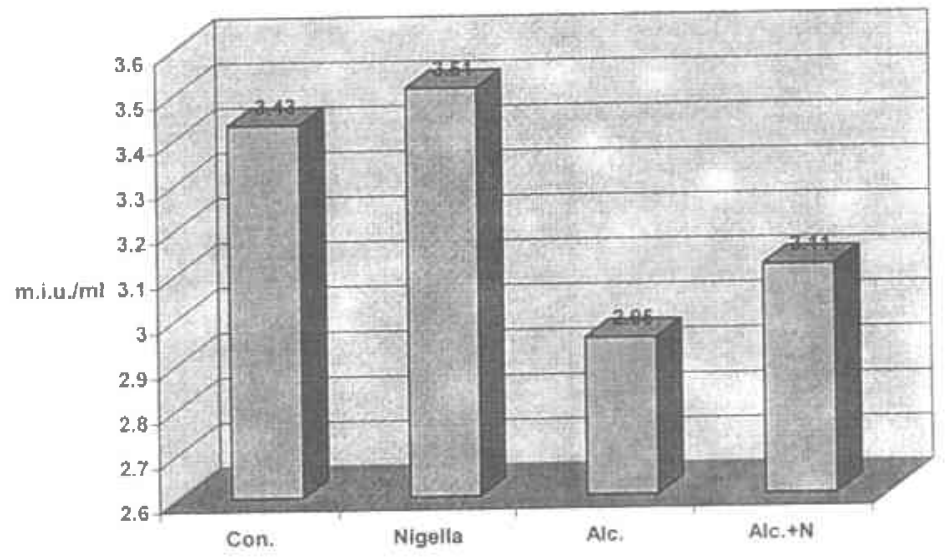

Fig. (4) : Senum LH level. 


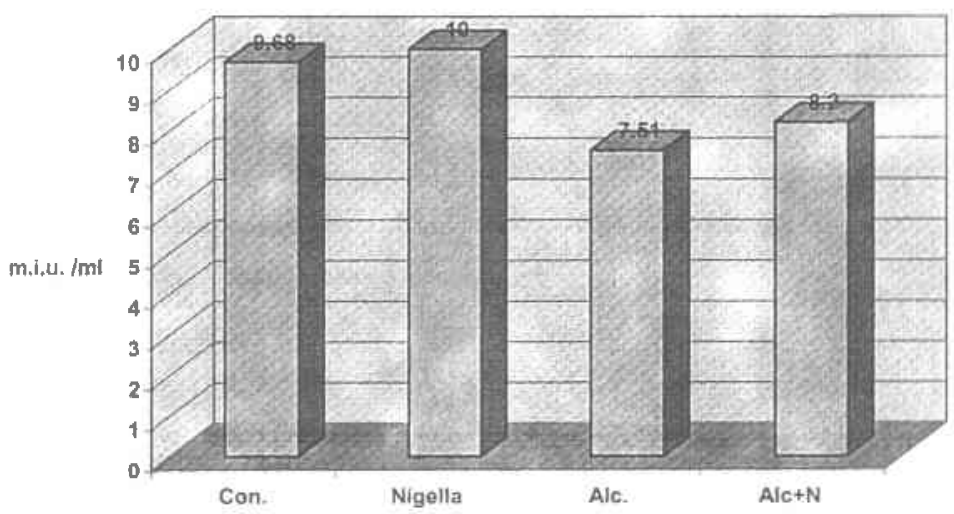

Fig. (5) : Serum ISII level.

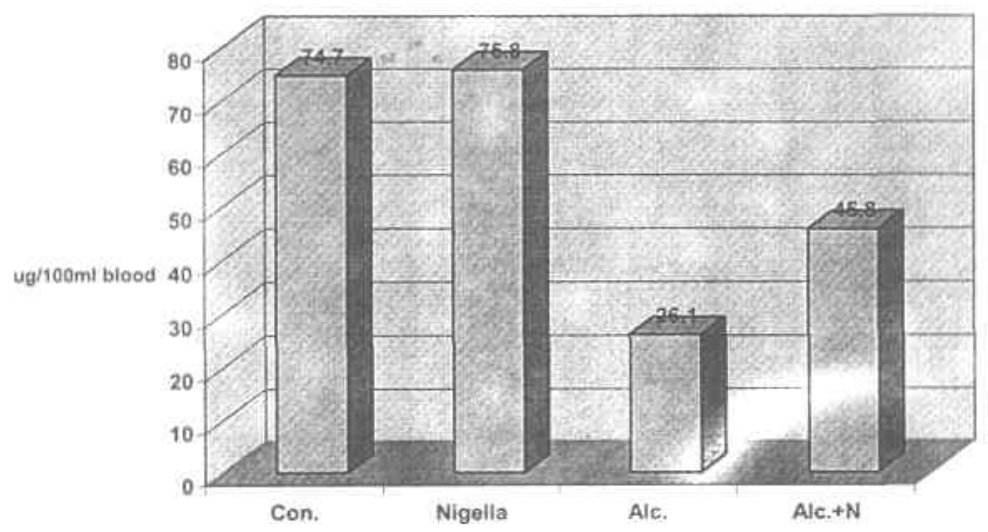

Fig. (6) : Sorum zinc level. 


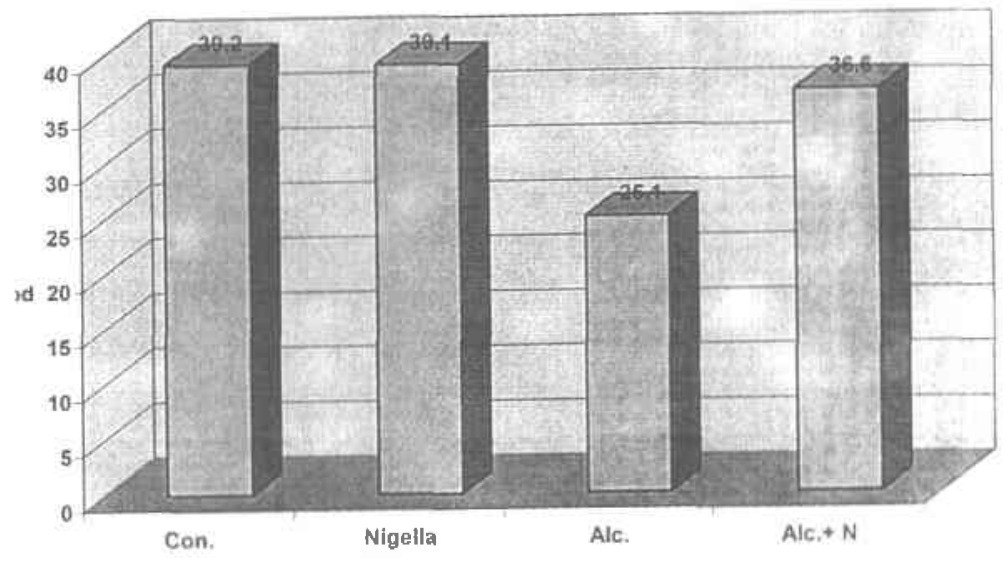

Fig. (7) : Serum copper level.

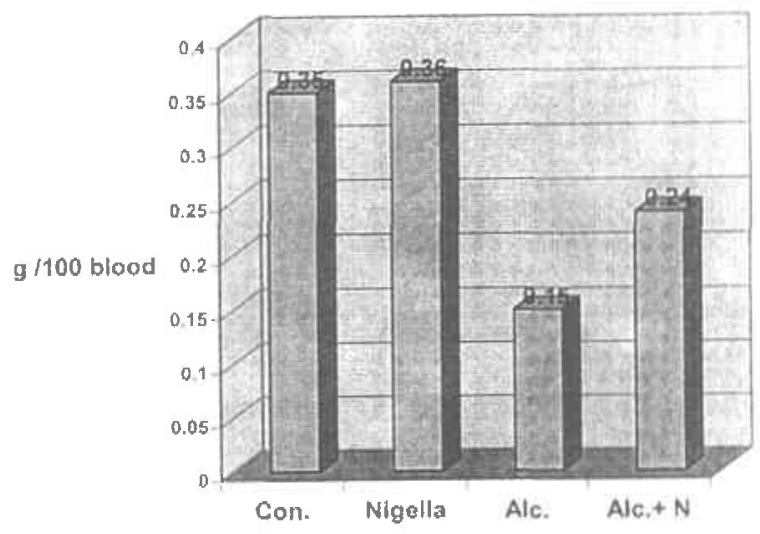

Fig. (8) : Strum sulenium lçvol. 


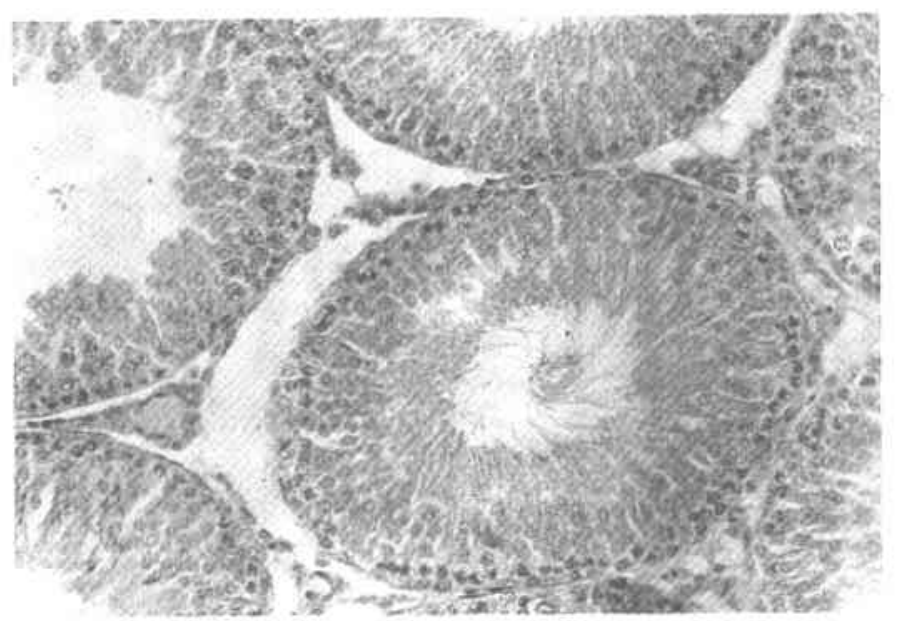

Fig. $(9$ - a) : Testicular morphology of a control tat. (H. \& E.; $\times 200)$

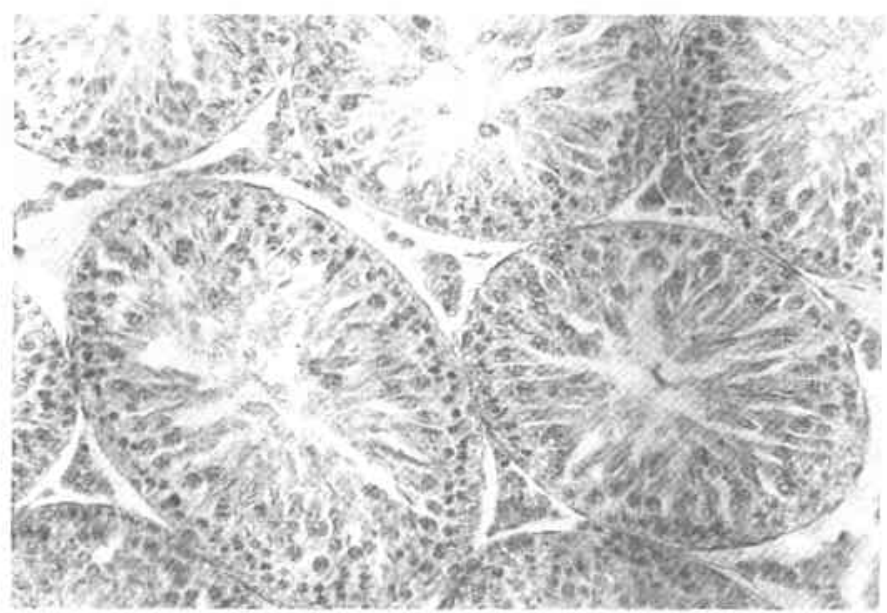

Fig. $(9 \cdot$ b) : Testicular pattem of a Nigella Sativa oil treated rat (group 2).

(H. \& E.; $\times 200$ ) 


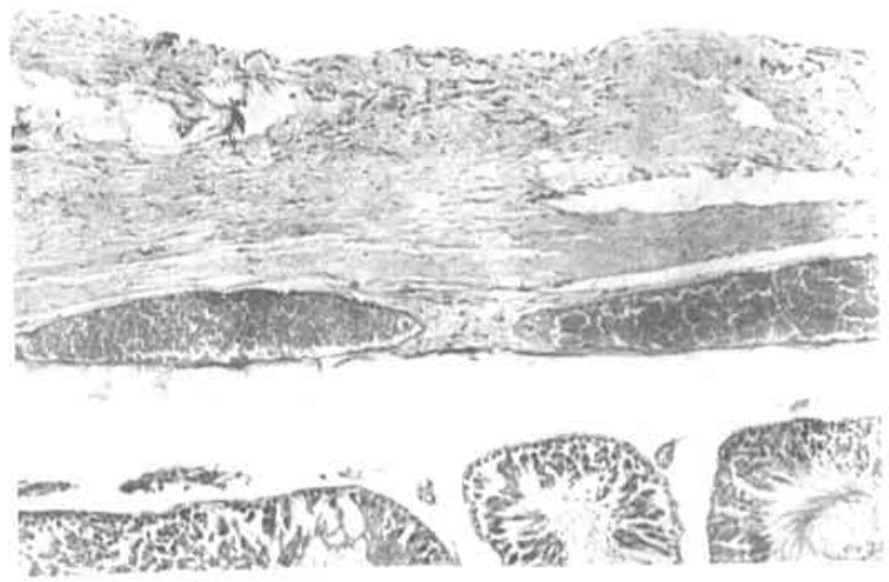

Fig. (10 - a) : A testis from rat adninistered alcohol alone shows dilated and congested capsular vessels.

(II. \& E: $: 100)$

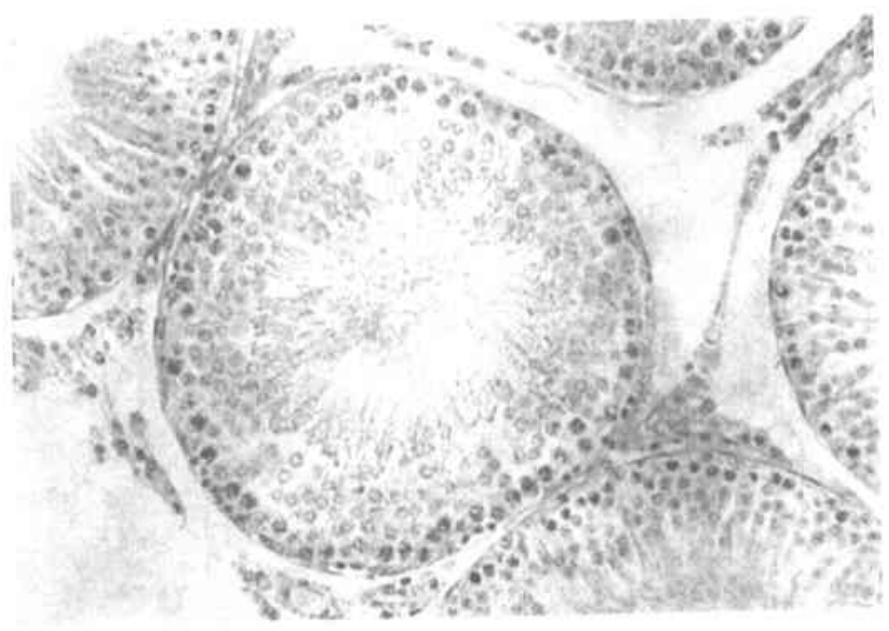

Fig. (10 - b) : A testicle of a rat from group (3) shows lymph edema in be tween seminiferous tubules.

(H. \& $\because \ldots 200)$ 


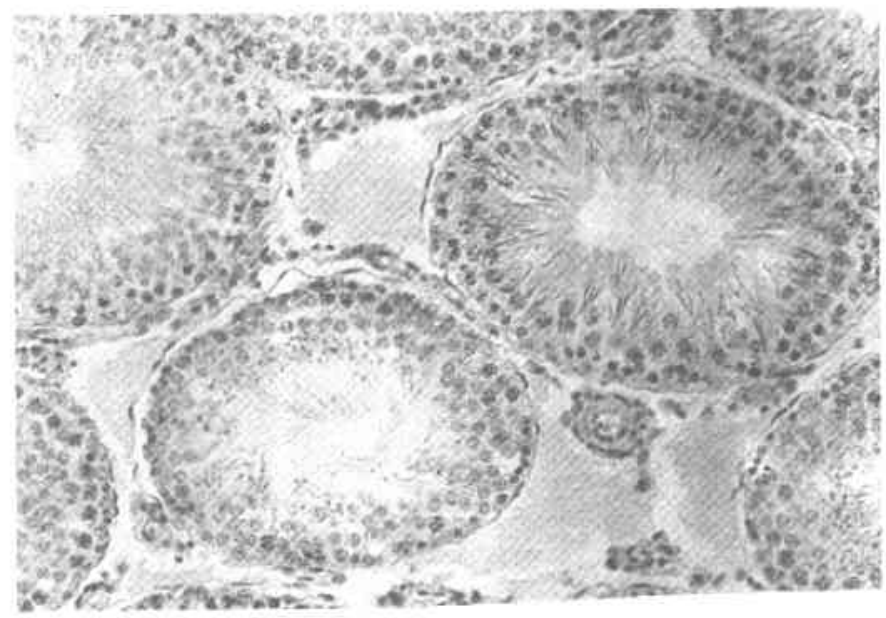

Fig. (11 - a) : An alcohol administered rat testicle shows partial separation of the basement membrane of the seminiferous tubule.

(H. \& E; $\times$ 200)

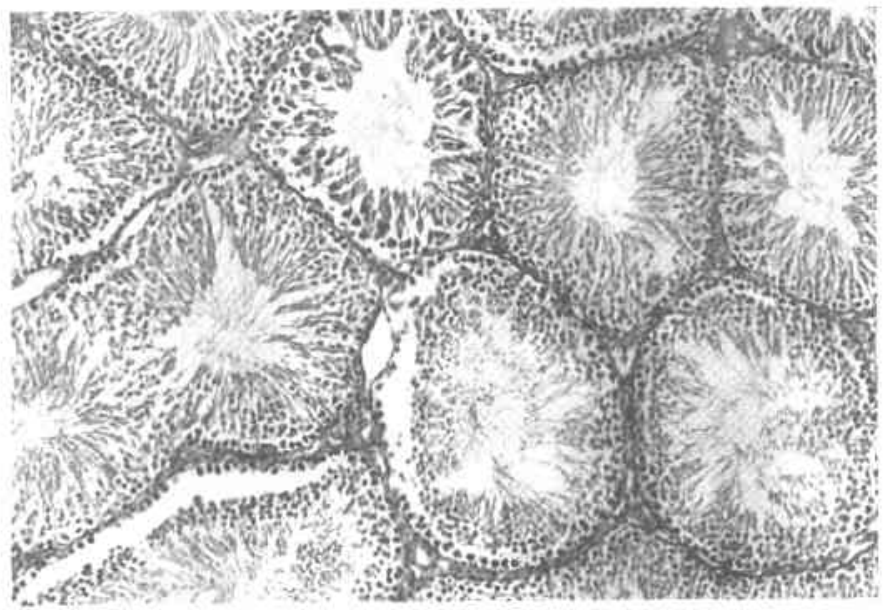

Fig. (14 - b) : The testicular morphology of an alcohol treated group reveals thickening of the hasement membrane of the seminiferous tubules.

(II. \& $\left.\Gamma_{+} ; \times 100\right)$ 


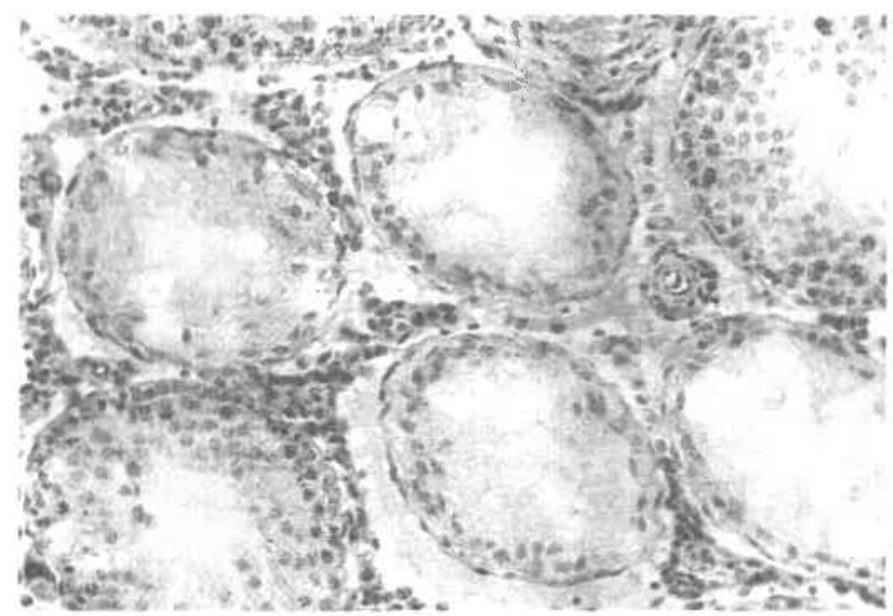

Fig. $(12-a)$ : Vacuoles are seen in the seminiferous fubule of the testis of an animal from group (3). The affected tubules show decreased numter of spematogenic cells.

(11. \& E: $\times 200)$

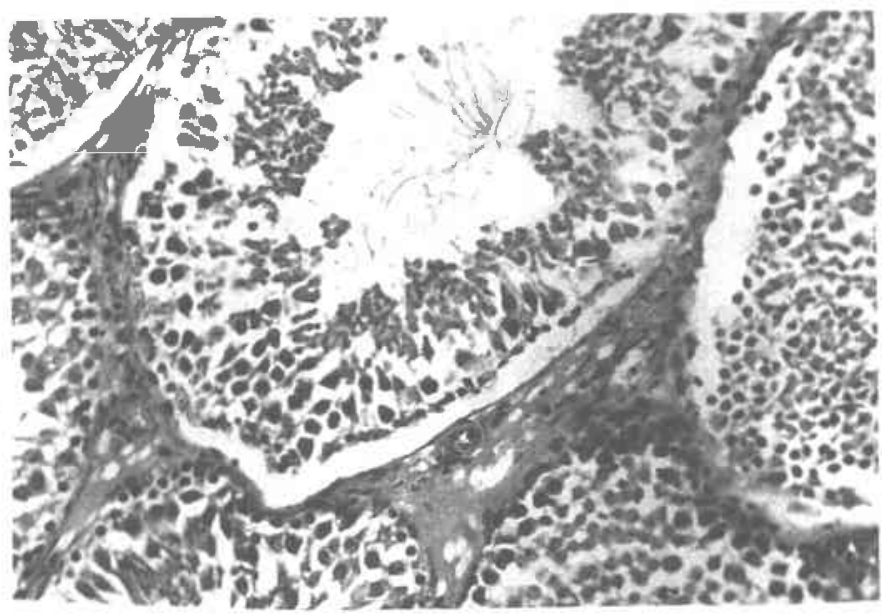

Fig. (12 - b) : A testis of a rat from group (3) reveals decreased number of leydig cells, hyalinization, edema and dilated congested blood vessels if the interstilial tissue.

(H. \& $\left.E_{*} ; \times 200\right)$ 


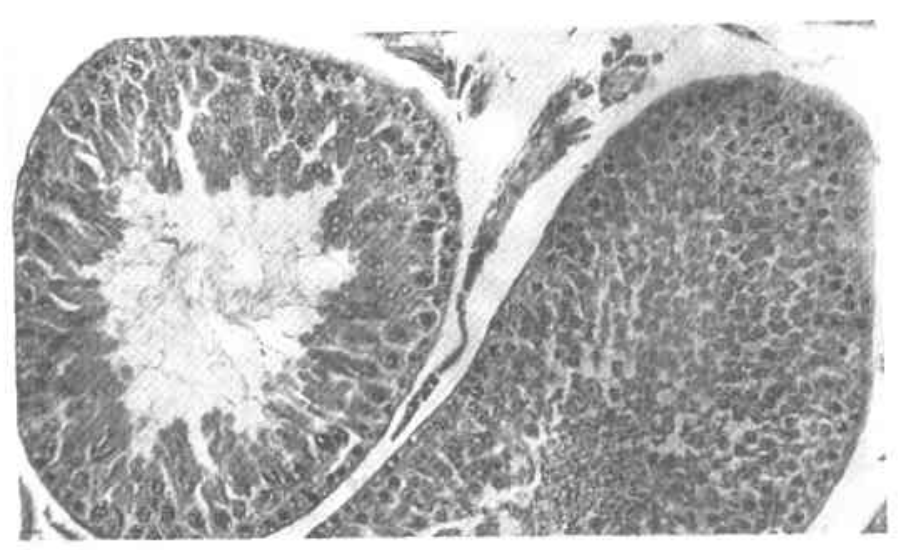

Fig. (13) : Testicular morphology of a rat from group (4) shows more or less the same morphology as the control group.

(H. \& E; x 200)

\section{DISCUSSION}

Alcohol is the most widely drug abuse in the United States and other countries. Unlike most other drugs, acohol carries the potential to damage many organs of the body including the heart, brain, liver, digestive system and the reproductive system. Essential information about alcoholism had come from studies with animals showing sensitivities and responses to alcohol similar to those of humans, so animal models were selected to the present work. Albino rats were chosen because they have many of the same biological and behavioral reactions to alcohol as humans, as regarding the male reproductive system (Salonen et al., 1992).

The present study revealed increased mortality rate between rats administered alcohol alone (group 3 ) but decreased in rats received alcohol and Nigella sativa oil at the same time (group 4). Increased mortality rate was most properly due to malnutrition, liver disease and multi-organ affection resulted from alcoholism. A decrease in body weight and food intake was significant in group (3). This might be for decreased appetite. This was in agreement with Gamal (2001) who reported that rats received alcohol for one month lost weight because alcohol stimulated leptin secretion. Leptin, is the hormone that regulates appetite, discovered in 1994. A slightly increased percentage of testicular weight in relation to body weight in alcohol 
treated group was due to reduction in body weight and increased testicular weight due to edema and congestion of the testicles.

Thiswork showed that chronic alcohol intake caused a profound testosterone suppression associated with decreased LH and FSH levels. Moreover, acute and chronic alcohol intake were associated with low levels of hypothalamic LHRH and pituitary LH in adult and pubertal male rat and inhibited testosterone secretion by the testes as well.

Also, chronic alcohol abuse produced sexual dysfunction and impaired sperm production in both human and animals (Yan and Jaffe, 1991; Bielawski and Abel, 1997; Hiney et al., 1999; Emanuele et al., 2001). The mechanisms of this alcohol induced damage have not been fully explained. Several possible mechanisms were described.

Testicular opioids when produced within the testes suppressed testosterone synthesis. One opioid, beta endorphin, had been increased with acute and chronic alcohol consumption. Similarly, beta endorphin produced in the hypothalamus resulted in decreased LHRH. In addition, opioids might increase apoptosis (programmed cell death). Apoptosis at the gonadal level would result in the death of Leydig cells as well as spermatogenic cells, leading not only to low testosterone level but also, to diminished sperm production (Nanji and Hiller, 1997; Yin et al., 1999).

Another cause for alcohol's harmful effects on testosterone production was decreased production of nitric oxide (NO). This NO is a vasodilator synthesized in the testes by nitric oxide synthetase enzyme. Inhibition of this enzyme by alcohol decreased production of NO. Thus there is no vasodilatation which resulted in accumulation of waste products that caused damage to Leydig cells and subsequent reduction in testosterone secretion (Azad et al., 1991).

Alcohol consumption might induce oxidative damage either by enhancing the production of toxic compounds called free redicals (byproducts of alcohol metabolism) or by decreasing the level of antioxidants (Polavarapu et al., 1998). Alcohol administration increased alcohol level in the blood. The body began to detoxify it l:" its conversion into acetaldehyde then into acetate. Acetaldehyde bound the red blood corpuscles' membranc making them more rigid and prevented them from easy passage into smaller capillaries. This reduced the oxygen supply to most of the cells of the body including the testicles.

Hypoxia in its turn reduced the ability of the cytoplasmic protein tubulin to assemble into microtubules. these microtubules provided a structural support for the cells. Without these microtubules, the cclls gradually atrophied and died off (Adams 
et al., 1992). Also, alcohol induced clevated levels of pituitaey prolactin and cytokins which might be responsible for suppression of testosterone secretion (Ogilvie and Rivier, 1997).

When testosterone level decreased, LH level did not increase as would be expected. This might be due to inability of the pituitary gland to respond appropriately to declined testosterone implied that alcohol had a central effect on the inter action between the nervous system and the endocrine system (Cooke et al., 1991).

Studies in alcohol - fed rats had established that decreased LH level resulted from impairment in both LH production and LH secretion. Alcohol could disrupt the functioning of the LHRH receptors or its interaction with LHRH, resulting in diminished LH release. Alcohol might affect the activity of LH molecule, rendering it less capable of stimulating hormone production in the testes. Therefore, alcoholic's deleterious effects on $\mathrm{LH}$ function were qualitative as well as quantitative (Emanuele et al., 1993).

The secretion of FSH was reduced by alcohol intake, but the exact mechanism was unknown; it might be due to increased level of estradiol. This estradiol enhanced the release of beta endorphin which suppressed the secretion of FSH (Hikim and Swerdloff, 1999).

Mark (1993), in contrast to the results of this study, reported that acute and chronic alcohol administration caused profound low testosterone level accompanied by normal LH and FSH levels. He supposed that the damaging effect of alcohol was localized to the testes and it had no central role.

Low levels of testosterone in adult men had been associated with a variety of medical problems including accelerated osteoprosis, decreased muscle and prostate functions, anemia, altered immune function and decreased reproductive ability (Cooke et al., 1991).

Dilatation and congestion of the capsular and interstitial tissue blood vessels detected in this study were due to allergy caused by the toxic eefect of alcohol itself, or its end products of metabolism. This roxicity also caused damage of the spermatogenic cells as it might affect the blood testis barrier. There was increased number of spermatogonia in highly affected seminiferous tubules. This was because spermatogonia proliferated to compensate decreased number of spermatogenic cells (Mark, 1993). Separation of the basement membrane of the seminifcrous tubules noticed in the present study was most probably due to oxidative injury resulted in disarrangement and ultimately destruction of himidesmosomes that joined the spermatogonia to the basement membrane (Mark, 1993). An adequate protein diet is 
important for maintaining cell structure as well as its cell membrane proteins. Alcohol affects protein nutrition by causing impaired and delayed digestion of proteins into amino acids in the small intestine and the liver (John, 2002; Emanuele and Nicholas, 2003).

The present study showed a reduction of the blood levels of $\mathrm{Zn}^{+2}, \mathrm{Cu}^{+2}$, and $\mathrm{Se}^{+2}$ after alcohol administration. The testicular damage could be explained by zinc and selenium deficiency. Zinc exerts a protective eefect on the activity of spermatogenic cells, possibly by preventing cellular damage caused by the oxidative stress (Marchesini et al., 1996).

The results of the present work revealed that administration of Nigella sativa oil for 30 days to alcohol administrated albino rats produced a significant improvement of physiological and morphological changes of the testicles if compared with albino rats administered alcohol alone. This might be due to the anti-oxidant properties of Nigclla sativa oil. Also. Nigclla sativa might enhance the production of nitric oxide which is a vasodilator that increases the blood supply to the testicles and other parts of the gonadal axis to remove the harmful waste products produced from alcohol metabolism (El-Kadi et al., 1987; Hassan and El Dakhakhny, 1992).

It appeared that alcoholic's damaging effects on reproduction were mediatcd at all three levels of male reproductive unit (hypothalamus, pituitary and gonads). Also, it is clear that Nigella sativa oil improved markedly these effects.

\section{SUMMARY}

The present work was designed to evaluate the protective effect of Nigella sativa oil on the morph - physiological changes of albino rat testes submitted to experimental chronic alcoholism. The rats were divided into four equal groups. Group (1), is the control group. group (2), was administered Nigella sativa oil alone, group (3), was administered alcohol for 30 days and group (4). was administered alcohol and Nigella Sativa oil at the same time for 30 days. All rats were decapitated after 30 days for blood examination and the testicles were dissected and prepared for histological examination.

The study revealed an increase in the mortality rate (20\%) and significant reduction of the body weight in group (3) compared to other groups $(\mathrm{P}<0.05)$. Blood examination showed a significant reduction in testosterone, $\mathrm{LH}$ and FSH lcvels ( $\mathrm{P}<$ 0.05 ) in the same group. There was also a significant reduction in blond level of 
trace elements, $\mathrm{Zn}^{+2}, \mathrm{Cu}^{+2}$, and $\mathrm{Se}^{+2},(\mathrm{P}<0.05)$. These changes, improved in rats administered Nigella sativa oil and alcohol at the same time group (4).

Moreover, histological examination of the testes of rats administered alcohol alone showed marked morphological changes in the lorm of decreased diameter of the seminiferous tubules, partial separation of the basement membrane of some scminiferous tubules, decreased number of Leydig cells and spermatogenic lineage cells. Oral administration of Nigella sativa oil with alcohol (group 4), caused improvement and reduction of the testicular changes. The diameter of the seminiferous tubules increased with increased number of both spermatogenic cclls and Leydig cells. The hormonal Level of Testosterone, LH and FSH showed improvement in relation to alcohol treated group, $\left(\mathrm{P}<0.05\right.$ ). In addition, the level of trace elements $\mathrm{Zn}^{+2}, \mathrm{Cu}^{+2}$. and $\mathrm{Se}^{+2}$ showed significant increase in relation to group $(3)(\mathrm{P}<0.05)$.

It is concluded that chronic alcohol intake affected the hypothalamo - pituitary gonadal axis; a system of endocrine glands and hormones involved in male reproduction. Also, it is recommended to give Nigella sativa oil as a treatment and protective to the toxic effecis of alcohol.

\section{REFERENCES}

1. Adams, M.; Nock, B.; Truone, R. and Cicero, T. (1992) : nitric oxide control of steroidogenesis : Endocrine effects of $\mathrm{N}$ - nitro L - arginine and comparison to alcohol. Life Sciences.. $50: 35$.

2, Aumann, K.D.; Bedoorf, N.; Brigelius, F.R.; Schommburg, D. and Flohe, L. (1997) : Glutathion peroxidase stimulation of catalytic cycle by computer-assisted molecular modeling. Biochemical and Environmental sciences, 10 (2 - 3) : 136.

3. Azad, N.; Argawal, M.; Kelley, M.; Mohaghepour, N. and Emanuele, N. (1991) : acute and chronic alcohol exposure hormonal disturbance. American journal of reproductive immunology 26 produced : 160 .

4. Bert, L.V. and Falchuk, K.H. (1993) : The biochemical basis of zinc physiology. Physiol, Rev., 73 : 97.

5. Bielawski, D. and Abel, E. (1997) : acute treatment of paternal alcohol exposure produces malformations in offspring's. Alcohol 14 (4) : 397.

6. Clarrk, L.C.; Dalkin, B. and Krongrad, A. (1998) : decreased incidence of prostate cancer with selenium supplementation. Br. J. Urol., 81 : 730.

7. Cooke, B.; Dirami, L.; Chaudry, M.; Choi, D. and Abayasekara, L. (1991) : Steroidgenrsis in rat testis Leydig cells. J. Steroid Biochem. Biol, $30: 466$. 
8. Eagon, P.K.; Teepe, A.G.; EIm, M.S.; Tadic, S.D.; Eply, M.J.; Beiler, B.E.; Shzuka, H. and Rao, K.N. (1999) : Hepatic hyperplasia and cancer in rats : alteration in copper metabolism. Carcinogen sis, J.. 20 (6) : $109 \mathrm{l}$.

9. El - Kadi, A.; Kandil, O. and Tabuni, A. (1987) : Nigella and cell mediated immunity. Arch. AIDs. Res. 1 : 232.

10. El Nimer, T.; El Enany, N. and Ali, A. (1996) : Trace elements analysis of renal stones. Egy. J. Physiol., 22 (1): 2 - 77.

11. El Nimer, T.; Hashem, A.A. and Asser, R. (1996) : Heroin dependence effects on some major and tracc clements. Biolog. Trace elements Res., $45: 153$.

12. El Dakhakhny, M.; Abd-el-Halim, M. and Aly, S. (2000) : Effect of Nigella Sativa oil on gastric secretion and ethanol induced ulcer in rats. Egypt. Sco. Pharmacol. EXP. Ther., $19(1): 71$.

13. Emanuele, M. and Nicholas, E. (2003) : National Institute on Alcohol Abuse and Alcoholism. Alcohol and Male Reproductive system.

14. Emanuele, M.; Halloran, M.; Uddin, S.; Tentler, J.; Emanuele, N. and Lawernce, L. (1993) : Effect of alcohol on the neuro endocrine control of reproduction. Research monograph No. 23,89.

15. Emanuele, N.; Lapagli, N.; Steiner, J.; Colantoni, A.; Van Theiel, D. and Emanuele, M. (2001) : Peri pubertal patemal Ethanol exposirc. Endocrine, 12 (2) : 213 .

16. Gamal, H. El-Sokkary (2001) : Quantitative study on the effects of chronic ethanol administration on the testis of adult male rats. (Abstract) NEL 22 (2) : 93.

17. Hassan, M. and EI Dakhakhny, M. (1992) : Effect of some Nigella Sativi Constituents on chemical carcinogen sis in hamster cheek pouch J. Egypt. Sco. Pharmacol. Exp. Ther, vol. Il No. 2 : 657.

18. Hikim, A. and Swerdlof, R. (1999) : Hormonal and genetic control of germ cell apoptosis in the testes. Revicw of Reproduction. $4: 38$.

19. Hiney, J.; Dearth, R.; Lara, F.; Wood, S.; Srivastava, V. and Dees, W. (1999) : Effect of ethanol on leptin sccretion. Induced leutinizing J. Alcoholism : clinical and experimental rescarch, 23 (11): 1785.

20. Jhon, H. (2002) : The health benefits of red wine and reservation Alcoholism $J$. (abstract).

21. King, J.C. (1990) : assessment of rinc status. J. Nutr.. 11: 1474.

22. Kullin, H.E. and Santiner, F.J. (1996) : The assessment of diminished testicular function in boys of pubertal age. Clin. Endocrinol. (Oxf). 25 (3) : 283. 
23. Marchesini, G.; Fabbri, A. and Zolis, M. (1996) : zinc supplementation and amino acid - nitrogen metabolism in patients with advanced cirrhosis. Hepatology, $23: 1804$.

24. Mark, J. (1993) : Alcoholism : Leaky gut syndrome. J. Alcoholism (abstract).

25. Nanji, A. and Hiller, S. (1997) : Apoptosis and necrosis in chronic liver disease. Alcohol Health \& Research World $21: 325$.

26. Ogilvie, K, and Rivier, C. (1997) : Gender difference in hypothalamic - pituitary - adrenal axis response to alcohol in rat : Activation role of gonadal steroids. Brain Research 766 (1 - 2) : 19.

27. Polavarapu, R.; Spitz, R.; Sim, J.; Folllansbee, M.; Oberley, L. and Rahemtulla, A. (1998) : Increased lipid per oxidation and impaired anti-oxidant enzyme function is associated with pathological liver injury in experimental alcoholic liver disease in rats fed diets high in corn oil and fish oil. Hepatology 27 : 1323.

28. Reported by : Michigan society for medical research (2003).

29. Salonen, I.; Pakarinen, P. and Huhtaniemi, I. (1992) : Effect of chronic ethanol in expression of gonadotropin genes in male rat. Journal of pharmacol and exper. Ther. $260: 463$.

30. Sharonova, I.N.; Vorobjev, V.S. and Haos, H.L. (2000) : Interaction between copper and zinc at GABA receptors in acutcly isolated ccrebellar cells of rat. British $J$, of pharmacology, $130: 851$.

31.Stlay, P.; Purr, W.A.; Cawoud, M. and Short, F. (1996) : The quantitative measurement of tcstosterone, estrogen, and progesterone in serum. Ann. Clin. Biochem. $23: 113$.

32. Thomas, K. (2003) : Alcoholism. Causes, Incidence, and Risk Factors. J. Alcoholism ; 1 - 5.

33. Vallee, B.L. (1998) : Zinc : biochemistry, physiology, toxicology and clinical pathology. Biofactors, $1: 13$.

34. Yan and Jaffe, R. (1991) : Reproductive Endocrinology, third ed Philadelphia : W.B. Saunders Co.

35. Yin, D.; Mufson, R.; Wang, R.; Shi, Y. (1999) : As - mediated cell death promoled by opioids. Nature 397 (6716) : 218. 


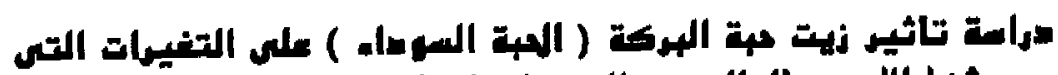

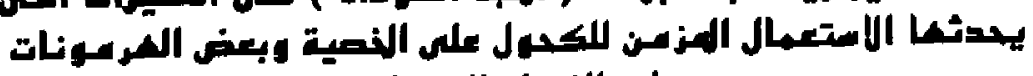
كير النتران البيضا.

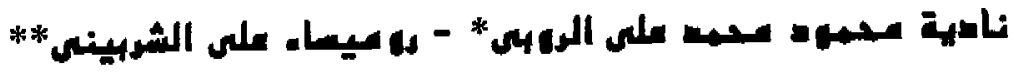

$$
\begin{aligned}
& \text { تسم الهستولوى - بكلية الطب - جامعة القاهرة: }
\end{aligned}
$$

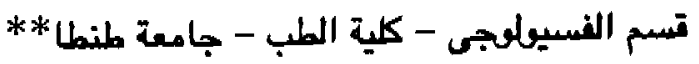

يهدف مذا البحث إلى دراسة تآيّر حبة البركة ( الحبة السوداء ) على التغيرات

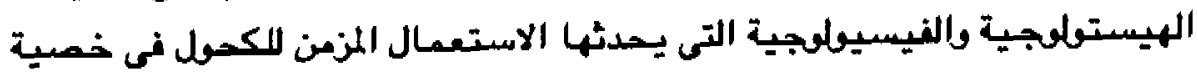

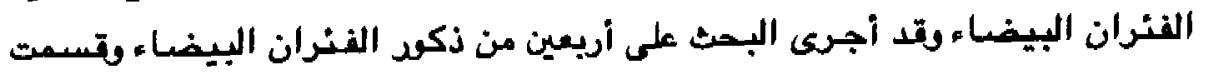

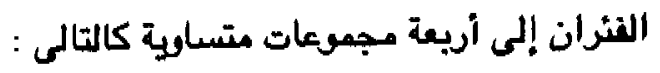

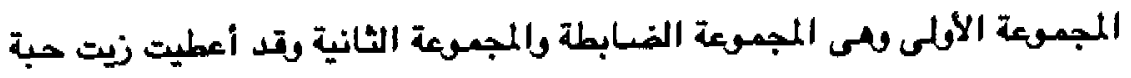

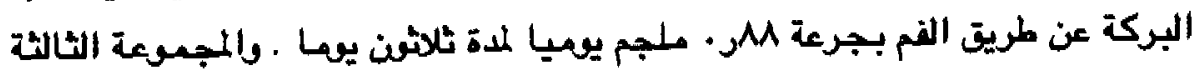

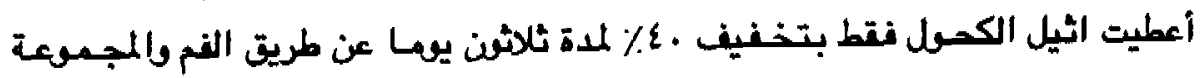

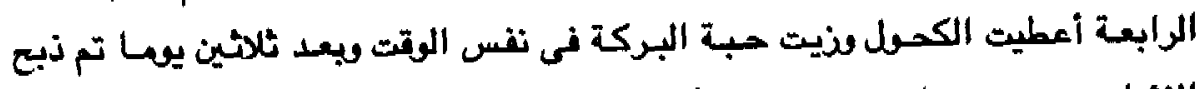

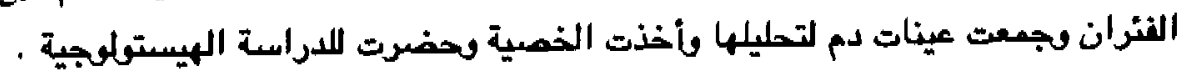

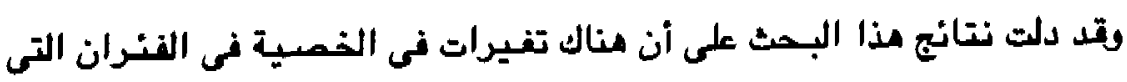

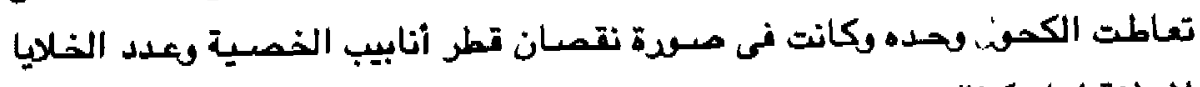

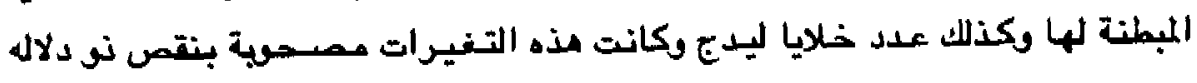

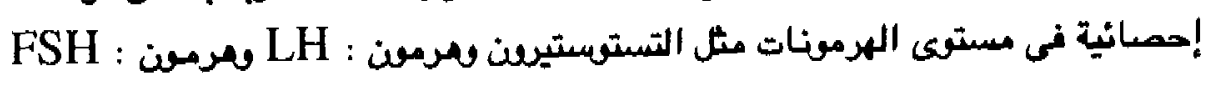

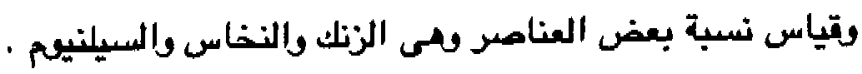


وقد تحسنت كثيرا مذه التغيرات بإعطاء زيت حبة البركة عن طريق الفم فى نفس

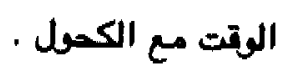

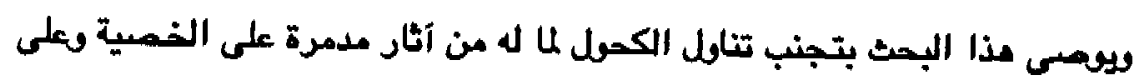

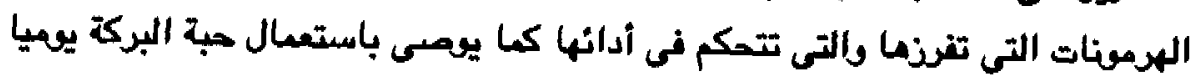

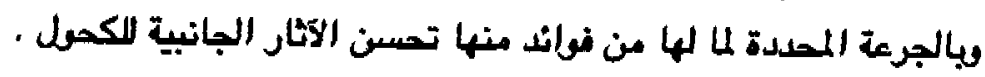

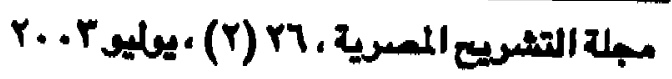

